\title{
Greek Diminutives in Gothic ${ }^{1}$
}

\subsection{INTRODUCTION}

As a broad generalization, the use of diminutives increased in the Greek language from non-attestation in Homer to the plentiful use of modern times. The New Testament stands in the midst of this trend, and employs diminutives in roughly the same proportions as other Koine Greek texts (Swanson 1958). The diminutives of the New Testament have not been extensively studied, but competent treatments have appeared in grammars (eg Moulton \& Howard 1929: 344-6, 375, 380) and articles (eg Elliot 1970: 391-8). An important contribution is that of D. C. Swanson, who in addition to situating the New Testament usage of diminutives in the Koine context, gave a summary of opinion on the subject down to 1958, before offering his own contributions.

Greek diminutives are formed with derivational suffixes attached to previously existing nouns. Unfortunately, the most common of these, -ion and -is (-id-), are also used in creating other derived forms. The situation is further complicated by the inexactness of the term 'diminutive', and the tendency of diminutives to lose their linguistic markedness over time (eg English 'baby', once the diminutive of 'babe', itself the diminutive of 'baban', all meaning 'infant'). ${ }^{2}$

Swanson therefore divides words with potentially diminutive endings into three conceptual categories: 1) deterioratives (expressing disdain) and hypocoristics (expressing affection); 2) true diminutives (expressing smallness), along with faded diminutives; and 3) words with other meanings altogether. Faded diminutives are those which once held a sense of smallness, but no longer clearly or necessarily do. ${ }^{3}$ With these distinctions in mind,

\footnotetext{
${ }^{1}$ The author is grateful to the editor and anonymous reviewers for their helpful suggestions; any mistakes of course remain his own.

${ }^{2}$ Often, the base noun will have taken on a secondary meaning, such that the diminutive begins to appear as the unmarked, natural way of expressing a thought: Once pais has the common secondary meaning of 'servant', paidion becomes the obvious word for child.

${ }^{3}$ The distinction between 1) and 2) is somewhat artificial, especially in the matter of faded diminutives: Faded hypocoristics and faded deterioratives are equally possible, if perhaps not relevant
} 
Swanson then offers a list (the same as Moulton's some years previously) of all the potentially diminutive nouns in the New Testament, grouping 1) and 2) together, and separating out 3), which are relevant neither to his study nor to the present investigation.

In order to investigate the outcome of Greek diminutives in Gothic, the Gothic rendering of all the words in Swanson's group of 1) and 2) has been checked. Some members of Swanson's list appear exclusively in the sections of New Testament lost in Gothic, and must regrettably therefore be ignored. The list of diminutives whose Gothic translation is attested is as follows: gunaikárion 'silly woman', thugátrion 'little daughter', thurís 'window', ichthúdion 'fish', korásion 'maid, girl', kerátion 'carob pod', klinídion 'bed', kunárion 'domestic dog', neanískos 'young man', onárion 'young donkey', opsárion 'small fish', paidíon 'child', paidárion 'child', paidískē 'servant girl', pinakídion 'writing tablet', ploiárion 'ship', pterúgion 'gable, pinnacle', strouthion 'sparrow', teknion 'child', psichion 'crumb', psōmíon 'morsel', ōtárion 'ear', and ōtion 'ear'.

Greek diminutives are not generally translated by Gothic diminutives, ${ }^{4}$ nor do(es) the Gothic translator(s) ${ }^{5}$ ever render a Greek diminutive with an equivalent Gothic base word (cf Seebold 1975: 157), modified by an adjective meaning 'small'. The base form behind some diminutives either does not appear in the New Testament, or not in those portions surviving in Gothic. In these cases, if the Gothic translation is not in and of itself remarkable, then little can be said. When both base and diminutive are present, often the Gothic translator takes no notice of the diminutive status of a given Greek word, and gives it the same translation as the Greek simplex form. In other cases, the diminutive is treated as an entirely separate lexeme, and translated with a Gothic word unrelated to that used to render

in the New Testament.

${ }^{4}$ For the formation of Gothic diminutives (and the state of the art as to the history of the Gothic text), see Miller 2019 especially 391.

${ }^{5}$ It is highly likely that many hands contributed to the Gothic Bible. Even if the ancient sources that attribute the translation to the historical Wulfila are substantially correct, they do not rule out his supervision of a workshop of multiple translators, or subsequent modifications. Cf eg Ratkus 2018. Equally, there seems at some point to have been a process of editorial regularization. The present paper does not contribute to or depend upon discussions of multiple translators, and uses the conventional 'Wulfila' to refer to the man, workshop, or process behind the text we have. 
the Greek simplex. ${ }^{6}$ Finally, where a Gothic diminutive is employed in translation, it is only ever to render some of the instances of the Greek word, and furthermore, as will be shown, is part of a Gothic pattern of diminutive use.

\subsection{TRANSLATIONS}

\subsection{Greek Diminutives with no corresponding Simplex}

Chart 1

\begin{tabular}{|c|c|c|c|c|}
\hline $\begin{array}{c}\text { Greek } \\
\text { Diminutive }\end{array}$ & $\begin{array}{c}\text { Greek } \\
\text { Simplex } \\
\end{array}$ & Attestations in Gothic Material & Gothic & English Translation \\
\hline \multirow[t]{3}{*}{ korásion } & & Mt 9:24.25; Mk 5:42, 6:22.28b & mawi & \multirow{3}{*}{ Maid, girl } \\
\hline & & Mk 5:41 & mawilo & \\
\hline & kórēe & Not in New Testament & & \\
\hline \multirow[t]{2}{*}{ neanískos } & & Mk 14:51b, 16:5; Lk 7:14 & juggalaups & \multirow{2}{*}{ Young man } \\
\hline & neanías & Not in surviving Gothic Bible & & \\
\hline \multirow[t]{2}{*}{ opsárion } & & Jn 6:9.11 & fisks* & Fish \\
\hline & ópson & Not in New Testament & & $\begin{array}{l}\text { 'boiled'; anything } \\
\text { eaten with bread }\end{array}$ \\
\hline \multirow[t]{2}{*}{ pterúgion } & & Lk 4:9 & gibla* & Gable / pinnacle \\
\hline & ptérux & Not in surviving Gothic Bible & & Wing \\
\hline \multirow[t]{2}{*}{ strouthíon } & & Mt 10:29.31 & sparwa* & \multirow{2}{*}{ Sparrow } \\
\hline & strouthós & Not in New Testament & & \\
\hline \multirow[t]{2}{*}{ psichíon } & & Mk 7:28, Lk 16:217 & drauhsna & Crumb \\
\hline & psíx & Not in New Testament & & Morsel \\
\hline \multirow[t]{2}{*}{ psōmíon } & & Jn 13:26b.27.30 & hlaifs & $\begin{array}{l}\text { Gk: morsel; } \\
\text { Go: bread }\end{array}$ \\
\hline & psōmós & Not in New Testament & & Morsel \\
\hline
\end{tabular}

Unsurprisingly, this group of diminutives is on the whole unremarkable, apart from

\footnotetext{
${ }^{6}$ This may call into question the inclusion of the words on Swanson's list of deterioratives, hypocoristics, and true diminutives, but that is not the purpose of the present investigation.

7 This reading is characteristic of the Byzantine family of New Testament manuscripts, which broadly includes the Gothic Version (cf Robinson \& Pierpont 2005: 167); otherwise simply apò tỗn piptóntōn 'from the fallings' without a noun to modify (cf Nestle-Aland 2012).
} 
the variation in the translation of korásion, which will be treated in conjunction with the material of Chart 8.

In some Greek manuscripts, neanískos appears twice in Mk 14:51, and it is this tradition that is followed by the Gothic Version. Psichion and psōmion are illustrative of the strange matrix of Gothic words for small items of food. The latter is John's word for the 'sop' with which Jesus indicates Judas as his betrayer. The Gothic hlaifs with which it is translated is also used for whole loaves, as at John 6:9, and for bread, as in the Lord's Prayer (Gk ártos in both cases), which senses it has in many other places throughout the New Testament. To the Gothic audience, only context would show that Jesus handed Judas a small piece of bread at the Last Supper, and not a loaf. Drauhsna, meanwhile, also translates klásma at John 6:12, although this is rendered with gabruka 'fragment' at Mark 8:8.19.20 and Luke 9:17, all from accounts of Jesus feeding the many.

\subsection{Diminutive and Simplex with same Gothic Translation}

\section{Chart 2}

\begin{tabular}{|c|c|c|c|c|}
\hline $\begin{array}{c}\text { Greek } \\
\text { Diminutive }\end{array}$ & $\underset{\text { Greek }}{\text { Simplex }}$ & Attestations & $\underline{\text { Gothic }}$ & English Translation \\
\hline thugátrion & & Mk 5:23, 7:25 & \multirow[b]{2}{*}{ dauhtar } & \multirow[b]{2}{*}{ Daughter } \\
\hline & thugátēr & $\begin{array}{l}\text { Mt 9:18.22, 10:35.37; Jn 12:15; } \\
\text { Lk 1:5, 2:36, 8:42.48.49; } \\
\text { Mk 5:34.35, 6:22, 7:26.29.308 } \\
\text { IICor 6:18; Neh 6:18 }\end{array}$ & & \\
\hline \multirow[t]{2}{*}{ ichthúdion } & & Mk 8:7 & \multirow{2}{*}{ fisks } & \multirow{2}{*}{ Fish } \\
\hline & ichthús & Lk 5:6, 9:13.16 & & \\
\hline \multirow[t]{3}{*}{ ploiárion } & & Mk 3:9; Jn 6:22.23 & \multirow{3}{*}{ skip } & \multirow{3}{*}{ Ship, boat } \\
\hline & & & & \\
\hline & ploĩon & Mt 8:23.24; Jn 6:17.18.19.21.22.24 & & \\
\hline ōtárion & & Mk 14:47; Jn 18:10 & \multirow{3}{*}{ auso } & \multirow{3}{*}{ Ear } \\
\hline \multirow[t]{2}{*}{ otíon } & & Jn $18: 26$ & & \\
\hline & oũs & $\begin{array}{l}\text { Mt 10:27; Lk 1:44, 4:21, 8:8, 9:44, } \\
14: 35 ; \text { Mk 4:9.23, 7:33, 8:18; } 1 \text { Cor }\end{array}$ & & \\
\hline
\end{tabular}

${ }^{8} \mathrm{~A}$ reading of Mark 7:30 including thugátēr is characteristic of the Byzantine family of New Testament manuscripts, which broadly includes the Gothic Version (cf Robinson \& Pierpont 2005: 88); otherwise, paidion. 
Ichthúdion, ploiárion, ōtárion and ōtion appear to be clear examples of faded diminutives. There is no discernible semantic distance between them and the simplexes on which they are built. Indeed, in the case of ploiárion, John switches from simplex to diminutive and back again within chapter six, all to describe the same vessel. Thugátrion might be thought to retain some sense of smallness or dearness, but there is alternative in both accounts in which it appears with thugátēr to refer to the same girl, so its significance cannot have been great.

Chart 3

\begin{tabular}{|c|c|c|c|c|}
\hline$\frac{\text { Greek }}{\text { Diminutive }}$ & $\frac{\text { Greek }}{\text { Simplex }}$ & Attestations & Gothic & English Translation \\
\hline kerátion & & Lk 15:16 & \multirow{2}{*}{ haurn } & Carob pod \\
\hline & kéras & Lk 1.69 & & Horn \\
\hline
\end{tabular}

The diminutive of Greek kéras 'horn' was used for the vaguely horn-shaped pod of the carob tree (and provides the first word of its Linnean name Ceratonia siliqua). The Gothic translation of kerátion as haurn, cognate with English 'horn', also used to translate kéras, has been regarded as surprising since the $19^{\text {th }}$ century (cf Jellinek 1893: 319). Three explanations are possible: 1 ) the translator was not paying attention to the sense of his text at this point, and translated without giving thought to the nonsense of eating horns; 2) the carob tree did not grow far enough north that the Goths were familiar with it, such that Wulfila did not recognize kerátion as anything but the diminutive of kéras, despite its incongruity in the story; or 3) because of the same similarity to horns which prompted the Greeks to call the carob pod kerátion, the Goths called it haurn.

Chart 4

\begin{tabular}{|l|l|l|l|l|}
\hline $\begin{array}{c}\text { Greek } \\
\text { Diminutive }\end{array}$ & \multicolumn{1}{|c|}{ Greek Simplex } & $\underline{\text { Attestations }}$ & $\underline{\text { Gothic }}$ & $\begin{array}{c}\text { English } \\
\text { Translation }\end{array}$ \\
\hline kunárion & & Mk 7:27.28 & \multirow{2}{*}{ hunds } & Domestic dog \\
\cline { 3 - 4 } & kúón & Lk 16:21; Ph 3:2 & & Dog \\
\hline
\end{tabular}

Kunárion seems ${ }^{9}$ to mean domestic dogs, as opposed to the stray and feral dogs of

\footnotetext{
${ }^{9}$ This statement is made in several Biblical and theological dictionaries (eg the entry by O. Michel in
} 
the Near East, called kúōn: An authentic case of diminutive morphology making an important distinction.

Example 2 ip Iesus qap du izai: let faurpis sada wairpan barna, unte ni gop ist niman Mark 7:27-28 hlaib barne jah wairpan hundam. ip si andhof imma jah qap du imma: jai frauja; jah auk hundos undaro biuda matjand af drauhsnom barne. kai élegen autễ, áphes prỗton chortasthễnai tà tékna, ou gár estin kalòn labeiin tòn árton tỗn téknōn kai toîs kunariois baleĩn. hē dè apekríthē kai légei autō̄, kúrie, kai tà kunária hupokátō tễs trapézēs esthíousin apò tô̄n psichión tô̄n paidión.

But Jesus said unto her, Let the children first be filled: for it is not good to take the children's bread, and to cast it to the (house-)dogs. And she answered and said to him, Yes, Lord: yet the house-dogs under the table eat of the children's crumbs.

Jesus' saying at Mark 7, at least as it appears in Gothic and English, ${ }^{10}$ is one of His harshest. In the pejorative reading encouraged by the English and Gothic translations, Jesus uses an insulting term for the Gentiles thought to have been common among Jews. ${ }^{11}$ 'Dogs' would here imply those outside the community of God's household. Jesus refuses to exercise His power for a woman because of her race, a particularly grievous act in the modern consciousness. In the reading encouraged by the Greek diminutive, things are slightly different: Jesus takes the insult-word, no doubt known to the woman, and moderates it by casting it in the diminutive and so referring to house-dogs; the thrust of the children / dogs comparison becomes the priority of the children, not their exclusive rights. Both the children and the pet dogs belong in the house and are entitled to food. ${ }^{12}$ This distinction is lost for the Goths, who, perhaps may not have had such negative associations with the simplex term, or may have read the saying in the most pejorative sense.

Chart 5

\begin{tabular}{|c|l|l|c|l|}
\hline $\begin{array}{c}\text { Greek } \\
\text { Diminutive }\end{array}$ & Greek & $\underline{\text { Attestations }}$ & Gothic & English Translation \\
\hline onárion & & Jn 12:14 & asilus & Young donkey \\
\hline
\end{tabular}

Kittel \& Friedrich 1985: 494), but no further source is cited. It is plausible, and in keeping with ancient terminology for things like geographical regions (where 'small' or 'lesser' describes the Romanized, domesticated portion of a larger territory like Germania, Asia, or Scythia).

${ }^{10}$ In the AV, NIV, ESV, ASV, RSV, NAB, etc.

${ }^{11}$ Which may appear in the Scriptures at Philippians 3:2, using of course kúōn.

12 Thus, Jesus requires her to acknowledge the priority of the Chosen People before he will work any miracle, not unlike Naaman bathing in the Jordan rather than the rivers of Damascus. Full discussion and citations in Keener 1999: 414-418. 
Gothic asilus is likely a borrowing from Latin asinus 'donkey', or its diminutive asellus.

It is used equally of the Greek base word ónos and its diminutive onárion, however, in circumstances where the diminutive must have force.

Example bigat pan Iesus asilu, gasat ana ina, swaswe ist gamelip: ni ogs pus, dauhtar 2 Sion, sai, piudans peins qimip sitands ana fulin asilaus.

John heurōn dè ho iēsoũs onárion ekáthisen ep'autó, kathṓs estin gegramménon, mè

12:14-15 phoboũ, thugátēr siôn: idoù ho basileús sou érchetai, kathếmenos epi pỗlon ónou.

And Jesus, when he had found a (Gk: young) ass, sat thereon; as it is written, Fear not, daughter of Sion: behold, thy King cometh, sitting on an ass's colt.

Gothic shares the borrowing of asinus / asellus with most of the languages of Northern Europe, where the donkey is not native. ${ }^{13}$ The Goths at least must have encountered the word through the Roman military. In any case, the Vulgate preserves the distinction, translating ónos with asinus, and onárion with asellus. ${ }^{14}$

\subsection{Multiple Gothic Translations}

\section{Chart 6}

\begin{tabular}{|c|c|c|c|c|}
\hline $\begin{array}{l}\text { Greek } \\
\text { Diminutive }\end{array}$ & $\begin{array}{l}\text { Greek } \\
\text { Simplex }\end{array}$ & Attestations & Gothic & English Translation \\
\hline \multirow[t]{4}{*}{ thurís } & & 2 Cor $11: 33$ & augadauro & Window \\
\hline & \multirow[t]{3}{*}{ thúra } & $\begin{array}{l}\text { Mt } 6: 6 ; 1 \text { Cor } 16: 9 ; 2 \text { Cor } 2: 2 ; \\
\text { Col } 4: 3 ; \text { Neh } 7: 1\end{array}$ & haurds & $\begin{array}{l}\text { Door (in sense of } \\
\text { panel) }\end{array}$ \\
\hline & & $\begin{array}{l}\text { Jn 10:1.2.7.9; Mk 1:33, 2:2, } \\
11: 4,15: 46\end{array}$ & daur ${ }^{15}$ & $\begin{array}{l}\text { Door (in sense of } \\
\text { doorway) }\end{array}$ \\
\hline & & Mt 27:60; Jn 18:16; Mk 16:3 & daurons & Two-winged door? \\
\hline klinídion & & Lk 5:19.24 & baditi & Bed \\
\hline & klínē & $\begin{array}{l}\text { Mt 9:2.6; Lk 5:18, 8:16, } \\
17: 34 ; \text { Mk 4:21, 7:4.30 }\end{array}$ & $\operatorname{ligrs}^{17}$ & Bed, mat \\
\hline
\end{tabular}

${ }^{13}$ Indeed, Gothic was very likely the vector of transmission for this word into the Baltic and Slavic tongues (cf Lehmann 1986: 45).

${ }^{14}$ Certain other early Latin translations (sometimes called Vetus Latina or Itala) have asinus in John $12: 14$ for onárion. It is not clear that asellus exemplifies normal diminutive semantics in the Classical language (Housman 1930).

${ }^{15}$ Also renders pulón at Mt 26:71; Lk 16:20: Hill \& Archer (1987) define pulón as 'properly, the passage which led from the street through the front part of the house to the inner court,' closed by a heavy púlēat the streetward end.' Púlēe, meanwhile is also rendered by Gothic daur at Mt 7:13.14; Lk $7: 12$.

16 Otherwise, krábattos: mat, camp-bed

${ }^{17}$ Also renders koíte at Rom 13:13, in the sense of fornication. 


\begin{tabular}{|l|l|l|l|l|}
\hline pinakídion & & Lk 1:63 & spilda $^{18}$ & Writing-tablet \\
\hline & pínax & Mk 6:25.28 & mes & Dish, charger \\
\hline
\end{tabular}

In all three of these cases, the Gothic translation of the diminutive differs from that of the simplex. In all three of these cases, however, the Greek diminutive expresses an idea substantially different from the root word. Their inclusion in this study is entirely due to their presence on Marchand's and Swanson's lists. They are clearly borderline cases at best, and there is nothing to observe about the Gothic translations of the diminutives.

Given that the semantic distinctions among these words are not related to the category of diminutives, in general the present study will not review them. It is perhaps noteworthy that the Greek simplex thúra is among the rare Greek words with three outcomes in the Gothic Version. The compilers of modern dictionaries of Gothic (eg Streitberg 2000: 56, Lehmann 1986: 179) have sought to distinguish haurds from the other two on etymological grounds: Derived from a Proto-Indo-European root meaning 'twist, weave', the word clearly comes to mean 'door' through a meaning like 'screen'. While closet doors such as those in Matthew 6:6 are regularly woven, it is ridiculous to suppose that the figurative doors of I Corinthians 16:9 or II Corinthians 2:12 must be woven. A far better explanation of the variants is that haurds refers to a door panel, while daur refers to the doorway (the aperture itself); in every case apart from Luke 7:12, this is uncomplicatedly the sense of the words. Meanwhile, the traditional translation of Gothic daurons is 'double door $^{\prime 19}$, although this is irrelevant to most of its attestations, such as the door to Jesus' tomb at Matthew 27:60. It is more likely that the daurons refers to a larger or grander entrance.

$\underline{\text { Chart } 7}$

\begin{tabular}{|c|c|c|c|c|}
\hline $\begin{array}{l}\overline{\text { Greek }} \\
\text { Diminutive }\end{array}$ & $\begin{array}{c}\text { Greek } \\
\text { Simplex }\end{array}$ & Attestations & Gothic & $\begin{array}{c}\text { English } \\
\text { Translation }\end{array}$ \\
\hline gunaikárion & & $2 \operatorname{Tim} 3: 6$ & qinein & Silly woman \\
\hline & guné & $\begin{array}{l}\text { Mt 5:28; 9:20.22; } 11: 11 ; 27: 55 ; \\
\text { Jn 16:21; } \\
\text { Lk 1:28.42, 4:26, 7passim, 8:43.47, 15:8; } \\
\text { Mk 5:25.33, 7:25.26, 10:12, 15:40; }\end{array}$ & qino & Woman \\
\hline
\end{tabular}

\footnotetext{
${ }^{18}$ Also used at 2Cor 3:3 for tablet of law (pláx)

${ }^{19}$ Streitberg 2000: 25, presumably because the word is a plurale tantum.
} 


\begin{tabular}{|l|l|l|l|}
\hline & 1Cor 7:16, 9:5, 11 passim; & & \\
& Gal 4:4; Col 3:18; 1Tim 2passim, 3:11; & & \\
& Skeireins VII:b & qens & Wife \\
& Mt 5:31.32, 27:19; & & \\
& Lk 1passim, 3:19,8:3, 14:20.26,16:18, & & \\
& $17: 32,18: 29,20$ passim; & & \\
& Mk 6:17.18, 10passim, 12passim; & & \\
& 1Cor. 7passim; Eph. 5passim; Col 3:19 & & \\
& 1Tim 3passim; Tit 1:6; Neh 6:18 & & \\
\hline
\end{tabular}

Gunê is another Greek simplex given multiple translations in Gothic, although here the distinct meanings of 'wife' and 'woman' are obvious to English speakers. Although gunaikárion, as a New Testament hapax, does not have multiple Gothic translations, its Gothic rendering qinein is of interest. The word is also used to translate thễlus 'female' at Mark 10:6 (beside gumein for ársēn 'male'), although qinakunds is used for the same word in same formulation at Gal 3:28 (beside gumakunds, also found at Luke 2:23). The nouns qinein and gumein are derived from the adjectives * qineins and $*$ gumeins, which in turn are derived from the simplex nouns qino and guma. The semantic trajectory is qino 'woman' > qineins 'female (adjective)' > qinein 'female (noun)'. Thus, qinein in this sense is the functional synonym of qinakunds, and the variation between the two is not particularly surprising. ${ }^{20}$ It is the use of qinein to translate the Greek pejorative diminutive gunaikárion which arouses more interest. It is possible that the Gothic translator recognized in gunaikárion a formation often used with de-adjectival nouns, and selected the Gothic word with the same derivation (cf Casaretto 2004: 329). This would be an almost unique translation decision in the Gothic New Testament, however. It is thus more economical to assume that the noun 'female' could have an occasional pejorative sense in Gothic just as it can in modern English and French.

\section{Chart 8}

\section{Greek} $\underline{\text { Greek }}$ Attestations $\underline{\text { Gothic }}$ English

${ }^{20}$ Except on the view of P. Scardigli (1973: 72), where qinein and all similar words are Gothic diminutives (presumably making the gunaikárion translation the semantically primary one, and the thễlus the secondary). 


\begin{tabular}{|c|c|c|c|c|}
\hline Diminutive & Simplex & & & Translation \\
\hline paidárion & & Jn 6:9 (cf Skeireins VII:a) & magula & $\begin{array}{l}\text { Child } \\
\text { cf Ger } \\
\text { Kindlein }\end{array}$ \\
\hline \multirow[t]{2}{*}{ paidíon } & & $\begin{array}{l}\text { Jn 16:21; Lk 1:59.66.80, 2:17.27.40, 7:32, } \\
9: 47.48,18: 16.17 ; \text { Mk 5:39.40.41, 7:28, } \\
9: 24.36 .37,10: 13.14 .15\end{array}$ & barn & Child \\
\hline & & Lk 1:76 & barnilo & $\begin{array}{l}\text { Child } \\
\text { cf Ger. } \\
\text { Kindlein }\end{array}$ \\
\hline \multirow[t]{4}{*}{ paidískē } & & $\begin{array}{l}\text { Mt 26:69; Mk 14:66.69; Jn 18:17; Gal } \\
4: 22.23 .30 b .31\end{array}$ & piwi & $\begin{array}{l}\text { Servant } \\
\text { girl }\end{array}$ \\
\hline & \multirow{3}{*}{ paĩs } & Mt 8:6.8.13; Lk 1:54.69, 7:7, & piumagus & Servant \\
\hline & & Lk 2:43, 9:42, 15:26 & magus & Child \\
\hline & & Lk 8:51.54 & mawi & Girl \\
\hline \multirow[t]{5}{*}{ tekníon } & & Jn 13:33 & \multirow[b]{2}{*}{ barnilo } & \multirow{2}{*}{$\begin{array}{l}\text { Child } \\
\text { cf Ger. } \\
\text { Kindlein }\end{array}$} \\
\hline & \multirow{4}{*}{ téknon } & $\begin{array}{l}\text { Mt 9:2, Mk 2:5, 10:24, 15:31; Gal 4:19; } \\
1 \text { Tim 1:18 }\end{array}$ & & \\
\hline & & $\begin{array}{l}\text { Mk 7:27, Mk 10:29.30, 12:19; Lk 1:7.17, } \\
3: 8,7: 35,14: 26,18: 29, \text { Lk 19:43, 20:31; Jn } \\
\text { 8:39; Rm 9:7.8b; 1Cor 7:14; 2Cor 12:14b; } \\
\text { Gal 4:25.27.28.31; Eph 2:3, 5:1.8; Phil } \\
\text { 2:22; Col 3:20.21; 1Thes 2:7; 1Tim 1:2, } \\
3: 4.12,5: 4 ; 2 \text { Tim 1:2, 2:1; Tit 1:4.6 }\end{array}$ & barn & \multirow[t]{3}{*}{ Child } \\
\hline & & Lk 2:48 & magus & \\
\hline & & 2 Cor 6:13 & frasts & \\
\hline
\end{tabular}

Paĩs and téknon are both fundamentally words for 'child', and are thus in a semantic field easily associated with diminutives. In some cases, like Mark 7:27-28, the words and their derivatives alternate seamlessly. Paiss, what is more, is a standard word for 'servant, slave', in common with usages such as German Knabe / Knappe, French garçon, and in some times and places, English 'boy'. The Gothic renderings of paĩs as piumagus and magus reflect this distinction: Magus means child, and the piu element (also present in piwi) indicates servanthood. Mawi is used in Luke 8 since the child in question, Jairus' daughter, is clearly a girl. The feminine diminutive paidiskē recalls the sense of 'servant', as is clear from passages like Mark 14:66 and Galatians 4:22, and receives the Gothic translation piwi 'servant girl'. Paidárion and paidion, on the other hand, are derived from paĩs in its sense of 'child'. Paidárion is taken by the Gothic translator as a true diminutive, and given the 
rendering magula 'little boy'.

Example 3 ist magula ains her, saei habaip 'e' hlaibans barizeinans jah ' $b$ ' fiskans; akei John 6:9 pata hva ist du swa managaim?

Éstin paidárion hỗde hòs ékhei pénte ártous krithínous kai dúo opsária; allà taũta tí estin eis tosoútous?

There is a (small) boy here, who has 5 barley loaves and 2 fishes; but what is that among so many?

The emphasis in 6:9 is on the meagreness of what is to hand: but five loaves and two fish, the packed lunch of a small child. Whether is was the uniqueness of paidárion in the corpus or the context of the verse which conditioned the Gothic translation, it was a discriminating choice.

Paidion, on the other hand, seems to be a faded diminutive, used to make the 'child' sense of paĩs perfectly clear, without any particular connotations of smallness or dearness. It shares its standard translation of barn with téknon. Téknon is also translated magus in Luke chapter 2, where both téknon and paĩs are used of the boy Jesus, and as frasts* in II Corinthians chapter 6 . The use of frasts* is not easily susceptible to analysis, since it is both a hapax legomenon in Gothic, and a word of uncertain etymology; indeed, since its only appearance is in the dative plural as frastim, the cited nominative singular is a reconstruction.

The remaining variation in the Gothic renderings is indicative of native Gothic diminutive use. Paidíon, teknion, and téknon are all translated as barnilo, the diminutive of barn, in situations where the child in question is addressed. The Benedictus makes this abundantly clear: Surrounded by barn renderings (Luke 1:59.66.80), the one time the child (John the Baptist) is directly addressed (Luke 1:76), barnilo is employed. Similarly, between 1 Timothy 1:2, where téknon is used to describe Timothy's relationship to Paul, and 1 Timothy 1:18, where téknon is in apposition to Timóthee (a vocative), the Gothic translator moves from barn to barnilo. It seems clear that children were not addressed simply as 'child' in Gothic; very likely such a usage would have seemed harsh or angry. Every case of barnilo 
is accounted for in this pattern. Alike is the one occasion (Mark 5:41: 'Little girl, arise') where korásion is translated as mawilo instead. Two counterexamples can however be offered where a child seems to be addressed but the Gothic diminutive is not used:

Example 4 barna, ufhausjaip fadreinam bi all; unte pata waila galeikaip ist in fraujin. Colossians tà tékna, hupakoúete toîs goneũsin katà pánta, toũto gàr euárestón estin en $3: 20$ kuríō. Children, obey your parents in all things: for this is well pleasing unto the Lord.

The standard English translation of this passage and those surrounding it, all of which contain injunctions to particular groups, implies that 'children' is a vocative. In fact, however, as the use of the definite article in Greek indicates, the groups named ('children', 'wives', 'fathers', etc) are in the nominative case, and represent not addresses, but itemizings. This would be enough to account for the Gothic non-use of the diminutive, except that the Gothic translator seems to have taken at least one of the other groups as vocative: In the next verse, Colossians 3:21, hoi patéres is rendered jus attans 'Ye fathers', a clear vocative. Thus, either the rendering barn is inconsistent, or jus attans is; since jus is not added to any of the other formulations, it is probably safe to regard it as the aberration, meaning that no counter-example of the Gothic diminutive pattern is found here.

Example 5 pu nu, barn mein waliso, inswinpei puk in anstai pizai in Xristau Iesu 2 Timothy sù oũn, téknon mou, endunamoũ en tễ cháriti tễ en Christō̃ iēsoũ 2:1 Thou therefore, my <true> child, be strong in the grace that is in Christ Jesus

There can be no real doubt the author of the epistle is addressing the téknon in 2 Timothy 2:1. The Gothic translation presents two divergences, one from its general pattern, namely the use of barn, and one from the Greek original. It may be that the latter accounts for the former: The Gothic translator has interpolated the word walisa* 'true, authentic' into the formulation 'my child', likely on analogy with 1 Timothy $1: 2$ and Titus $1: 4$ (cf Bammesberger 1980: 1). It is likely that barn is also an effect of the influence of these other verses. Additionally, it is possible that the hypocoristic effect of walisa* was sufficient to remove whatever sting an undiminutivised word for child may have held in Gothic. 


\subsection{CONCLUSIONS}

One way to view many of the translations of Greek diminutives in Gothic is as advertisements for the process that gives us the Gothic Version. Sufficient knowledge of the Greek of three centuries previous was included to disregard faded diminutives like paidion, while preserving the sense of paidárion. It distinguished between the two meanings of words like paĩs or guné. Perhaps most notably, it introduced the native Gothic pattern of diminutive use in addressing children into the text. Alongside these credits, certain limitations would have to be noted. The lack of any recognition of the distinction between ónos and its diminutive onárion impoverishes the translation. Even without a Gothic simple / diminutive pair, an adjective modifying asilus could still have been used to convey the meaning to the Gothic audience. Kunárion and kúōn amount to a similar, if less clear cut (because the force of the diminutive is a theological conjecture) example of the translation failing to reproduce an original distinction. In this case, of course, the Gothic translator is in the company of the Authorized Version committees, and several other well-regarded renderings.

Another approach, perhaps preferable, is to focus on which Gothic linguistic phenomena assert themselves in the translation despite lacking Greek analogues, and which Greek phenomena do not. Here we may note that the contrasts kunárion / kúōn or onárion / ónos are not replicated in Gothic. It may be concluded that animal diminutives were not an important feature of the language. On the other hand, the use of the diminutive in forms of address for children (or perhaps, accounting for 2 Timothy 2:1, the avoidance of simple vocatives for 'child') seems to have been sufficiently fundamental in Gothic to appear in several contexts.

Thus, targeted considerations of linguistic phenomena such as the present study may contribute to scholarly understanding of the translation decisions, practices, and priorities of a text like the Gothic Version, and also begin to draw out patterns of natural language 
usages unnoticed in standard accounts.

\section{Works Cited}

Aland, B., K. Aland, J. Karavidopoulos, C. M. Martini, and B. M. Metzger, eds (2012), NestleAland - Novum Testamentum Graece, $28^{\text {th }}$ revised edition, Stuttgart: Deutsche Bibelgesellschaft.

Bammesberger, A., 1980. 'Gotisch Walisa: Ein etymologischer Versuch aus der Sicht der Wortbildungslehre', Beiträge zur Geschichte der deutschen Sprache und Literatur (PBB) 102.

Casaretto, A. (2004). Nominale Wortbildung der gotischen Sprache: Die Derivation der Substantive. Heidelberg: Winter.

Elliot, K., 1970. 'Nouns with Diminutive Endings in the New Testament', Novum Testamentum, 12:4.

Hill, G. \& G. Archer, 1987. The Discovery Bible New Testament. Chicago: Moody.

Housman, A. E., 1930. 'The Latin for Ass.' Classical Quarterly 24: 11-13

Jellinek, M. H., 1893. 'Gotica Minima', Zeitschrift für deutsches Altertum und deutsche Literatur (HZ) 37.

Keener, C. S., 1999. A Commentary on the Gospel of Matthew, Grand Rapids: Eerdmans.

Kittel. G. \& G. Friedrich, 1985. Theological Dictionary of the New Testament, abridged, Grand Rapids: Eerdmans.

Lehmann, W., 1986. A Gothic Etymological Dictionary, Leiden: Brill.

Miller, D. G., 2019 (forthcoming). The Oxford Gothic Grammar. Oxford: OUP.

Moulton, J. H. \& W. F. Howard, 1929. A Grammar of New Testament Greek, II, Edinburgh: T \& T Clark.

Ratkus, A., 2018. 'Greek ápxıعpeús in Gothic translation: Linguistics and theology at a crossroads' in NOWELE 71(1): 3-34.

Robinson, M. A. \& W. G. Pierpont, 2005. The New Testament in the Original Greek: Byzantine Textform. Southborough: Chilton Book Publishing.

Scardigli, P., 1973. Die Goten: Sprache und Kultur. Munich: C. H. Beck.

Seebold, E., 1975. 'Archaic Patterns in the Word Formation of Early Germanic Languages', 
Transactions of the Philological Society, 74:1

Streitberg, W., 2000[1908]. Die gotische Bibel 2. Teil: Gotisch-griechisch-deutsches Wörterbuch. 6. Auflage. Heidelberg: Winter.

Swanson, D. C., 1958. 'Diminutives in the Greek New Testament', Journal of Biblical Literature, 77:2, 131-51. 